\title{
IV Festival UCSUR de Teatro Internacional: Cultural Diversity in Contemporary Latin American Theatre
}

\section{Jimmy A. Noriega}

The IV Festival UCSUR de Teatro Internacional was celebrated from April 18-25, 2009, in Lima, Peru. During the eight-days of festivities, sixteen plays from eight countries were presented as a celebration of cultural diversity. Bringing together professional artists and university students, the festival placed an emphasis on instructive interaction, featuring a series of creative workshops led by guest performers, a three-day academic conference, and two critical roundtables that offered in depth analyses of the plays presented during the week. Percy Encinas Carranza, director of the festival, introduced the invited artists and their work by noting: "No sólo constituyen una insuperable lección de distintos modos de hacer teatro, sino, además, un muestrario intercultural de distintos modos de apreciar la vida."

Sponsored by the Universidad Científica del Sur (UCSUR), the first festival, featuring six plays, was held in 2005. Since its premier, the international festival has continued to grow and draw artists from across Latin America and the globe. Subsequent celebrations in 2006 and 2008 brought together artists from the Americas and as far away as Spain and Lithuania. This year's festival, the largest to date, featured eight countries: Peru, the Dominican Republic, Argentina, Spain, Mexico, Ecuador, Colombia, and the United States.

The official inauguration of the festival took place on Saturday afternoon with a small parade that circled around the Parque de la Felicidad de San Borja. Festival participants, led by the local musical group Yawar de Perú, joined in celebration as masked musicians played drums and wooden flutes. Costumed in bright colors and accompanied by actors on stilts dressed as giant puppets, the parade attracted the attention of locals who formed a crowd as the group danced through the streets. After circling the park, an audience 


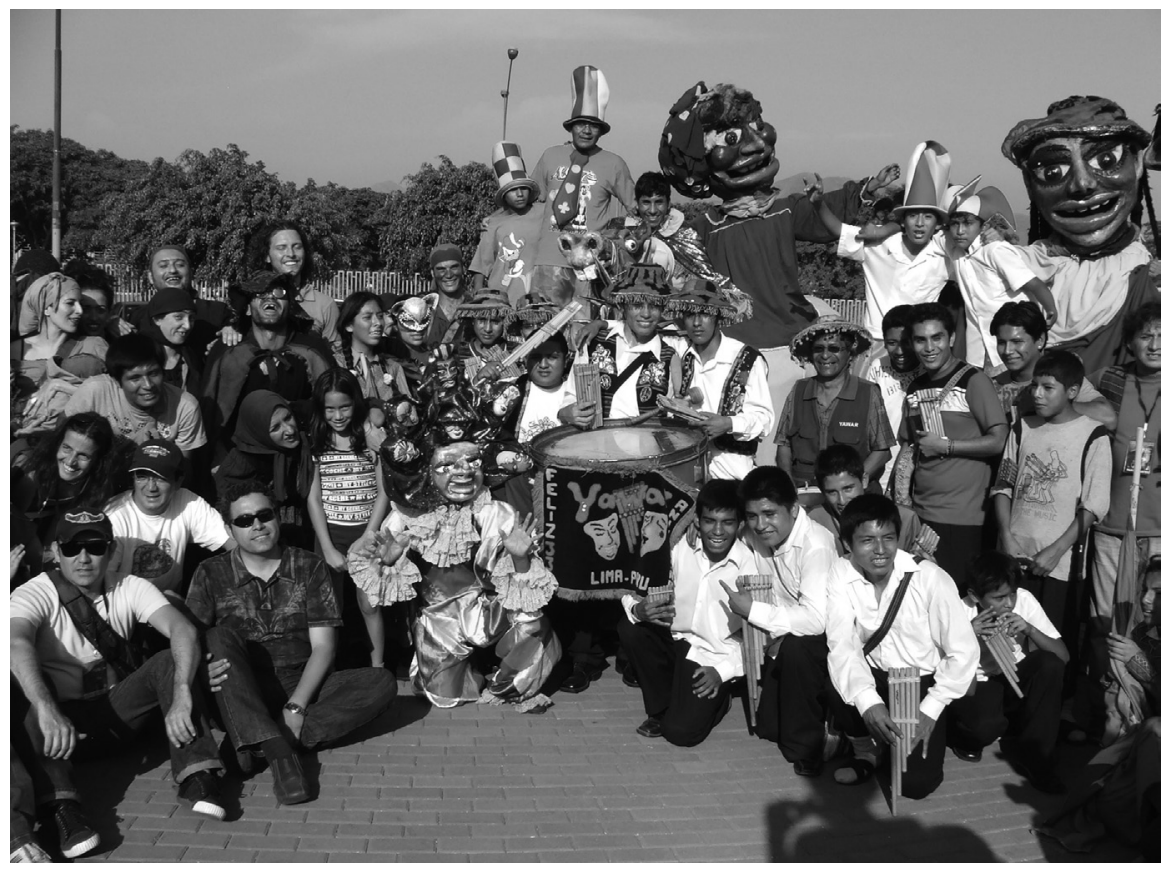

Festival Participants and Yawar de Peru-Parque de la Felicidad, San Borja Photo: Jimmy A. Noriega

gathered around an open-air stage to watch as Grupo Cultural Yuyachkani performed their 1983 classic Los músicos ambulantes. The play, a musical comedy about four animals traveling to Lima to become musicians, features the many different musical styles of Peru set against a story that highlights the political and social conditions of the country. Yuyachkani, promoting a message of racial diversity and understanding, appropriately opened the festival which was celebrating cultural diversity and unity through theatre. The play, which highlights the cultural differences of its characters, unites them by speaking of their cuatro ritmos pero un corazón. By the end of the week, the sentiment of the festival could be described in the same way: sixteen different theatre groups united by un solo corazón.

After a short bus ride to the Ella Dunbar Theatre, Josefina Báez opened the international part of the festival with her solo performance Dominicanish. Self-described as a Dominican-York artist, Báez is the founder and director of Ay Ombe Theatre. First staged in 1999, the play is an autobiographical performance piece that blends language, culture, music, and media. Accompanied by a solo trumpet, Báez creates a character who although 
alienated from the dominant national culture is able to use that marginality as a way of connecting with the other cultures she encounters. The title of the piece, Dominicanish, refers to Báez's creation of her own language - one created between cultures - to define herself and the world in which she lives. The piece is bilingual in soul as well as language, and the audience enjoyed the humor and contrast as Báez twisted between unexpected, hilarious, and heartbreaking moments of personal and social conflict.

Cuatro historias de cama, by Peruvian author Eduardo Adriánzen, was presented by Espacio Libre of Lima in Sala Alzedo the following evening. Under the direction of Diego la Hoz, the play - a critical commentary on the relationships that people forge amid conflict, compromise, and confusion - is divided into four scenes, each featuring a different couple. Double cast with two men and two women, the actors never leave the stage. The first two scenes, featuring young heterosexual couples, are about relationships coming to an end. The third story presents the audience with two sisters as they come to terms with the older sister's terminal illness and their attempt at mending their rocky relationship. The final scene, between two young men who have

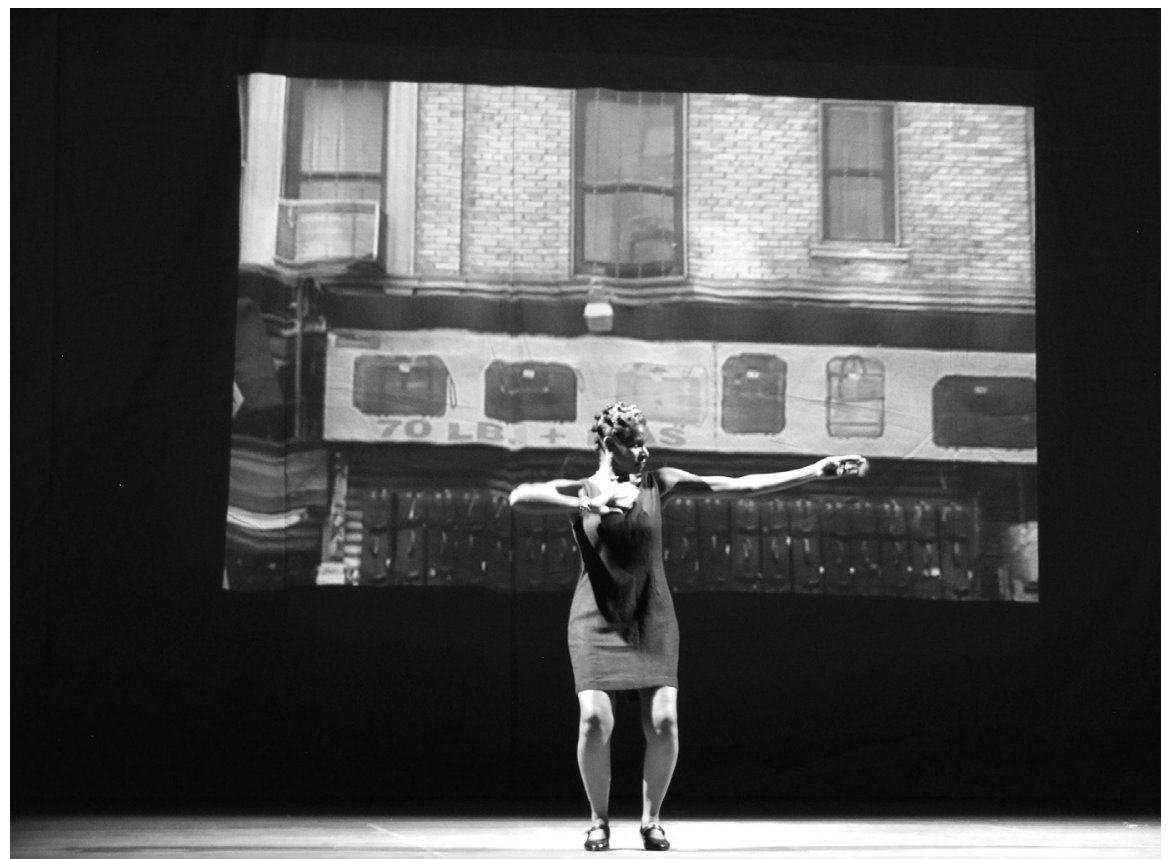

Josefina Báez—Dominicanish. Photo: Jimmy A. Noriega 
just had sex, raises issues of sexuality, machismo, and the coming-out process. Throughout all four scenes, the fifth character - the bed - creates the space for each couple to open up about love, death, disappointment, honesty, and self-discovery. The intimacy of the bedroom provides a space for vulnerability and closeness, a metaphor meant to stand in place for the larger world in which human relationships are torn apart and often taken for granted.

On Monday evening, artists from Buenos Aires presented Roberto Perinelli's Desdichado deleite del destino. The play, nominated in Argentina for five Premios Ace in 2008, was masterfully directed by Corina Fiorillo and featured performances by three skillful actors: Nacho Vavassori, Belén Brito, and Nelson Rueda. The play is a look at the relationship between a dictatorial father and his quiet and disheartened daughter and is a riotous commentary on tyranny and revolt. Unmistakably Argentine in flavor, the play highlights the popular customs of the nation: the drinking of mate, obsession with soccer, the cultivation of roses, and its popular music. Throughout the play the authoritative father - loud, powerful, and controlling — has created a situation where his daughter is unable to express herself. Under this constant form of oppression, the daughter is left with few options, and the result is both shocking and cathartic. A commentary on authority and subjugation, the play liberates the female voice while exposing the menace associated with an excessively macho ego.

The next evening, inside the beautiful Teatro Segura, the group Atalaya de España presented its version of the Spanish classic Divinas palabras. The group, which last year celebrated its 25 th anniversary, was the recipient of Spain's 2008 Premio Nacional de Teatro. Ramón María del Valle-Inclán's play takes place in Galicia, Spain, and revolves around the story of a hydrocephalic child who is taken throughout the province by its mother to beg for money. When the mother dies, the child becomes the object of a custody battle as the characters in the play fight to take advantage of the child's ability to generate pity and money by publicly displaying its warped body. Commenting on the grotesque qualities of avarice, lust, greed, and adultery, Divinas palabras lies somewhere between the borders of morbid comedy and social commentary. Under the direction of Ricardo Iniesta, the actors were accompanied on stage by a dozen large wooden spools that were manipulated to create a series of images and sets that were beautiful and provocative. The play, a visual delight of costumes and stage pictures, unfortunately got caught up in the spectacle of its staging and most of the narration was lost in the commotion. 
Mestiza Power, presented by the group Sa'as Tun of Mexico, was presented the following evening in the same venue. Written and directed by the group's founder, Concepción León Mora, the play is based on interviews she conducted with indigenous women in and around the city of Mérida. Mestiza Power merges the indigenous traditions of the Yucatan peninsula with the modern conditions in which the women live. Pairing the image of the sensual and powerful female body with the social, racial, and economic violence that is enacted upon these women daily, the play gives voice to the marginalized community of indigenous women. Sa'as Tun, in their work, draws upon the rituals, myths, and essence of the Mayan culture to weave a visual and oral story of struggle and survival. Part storytelling, part testimonial theatre, the play is divided into two parts: a series of interweaving dialogues between Mayan women over the subjects of memory, childhood, culture, and education, and three monologues. The women presented on stage include a domestic worker, a street vendor, and a mystic herbalist. The play, as its author explained, shows that that Mayan culture is not a relic of the past, but a very present and evolving force that negotiates daily with the conflicting powers of modernity.

Contraelviento, from Ecuador, also drew upon its local indigenous traditions for its play, La flor de la chukirawa, which was presented on the sixth night of the festival. The group, founded in 1991 under the direction of Patricio Vallejo Aristizábel, has presented the play in almost a dozen international theatre festivals over the past few years. Brilliantly acted by Verónica Falcón, Nelson Morillo, and Sara Zambrano Moreno, the characters become the centerpiece of this story. Staged as an interview with a mother from the mountains of Ecuador, the play tells the story of a young man who left to explore the world and ended up fighting on the side of the U.S. army in Iraq. When the news reporter asks the mother about her son's death, her narration of the events weaves between both worlds, past and present, as her words bring her son to life on the stage. The play is about hardship, strength, and survival. Like the flower of the title, the mother is colorful and vibrant, with roots grounded firmly in Andean culture; but she is also able to protect herself from the harsh world in which she lives. Contraelviento's work is divided between artistic creativity and social exploration: the poetic language of the play and its stylized movements blend effortlessly with the political and social conditions of its characters.

Cuer2, a theatre collective formed under the direction of university professor Roberto Sánchez-Pierola, was the second professional group from 
Lima to present work at the festival. Founded in 1999, the group has presented its original pieces in festivals throughout Peru, as well as in Ecuador and Chile. Their newest collaborative piece, Interruptor, follows Brecht's premise that children at play (pretending to be adults) will reveal as much about the adults portrayed as the children playing the games. In this case, the two young boys create a game where they constantly transform their bodies into different men and women, offering commentary on everything from the internet, to celebrity gossip, to global warming. In a series of vignettes dealing with issues of mass communication, technology, and globalization, the two actors portray a world dominated by an inability to communicate and relate with others. Throughout the stage, cell phones, computers, television sets, keyboards, and various electronics surround the young boys and become the focal points of these games. In this performance, the members of Cuer2 are confronting the audience with an important question: At what point do these modern means of technology, meant to enhance communication, become the source of man's increasing state of isolation? Coming directly into the audience to break the divide of the fourth wall, a form of theatrical isolation, the

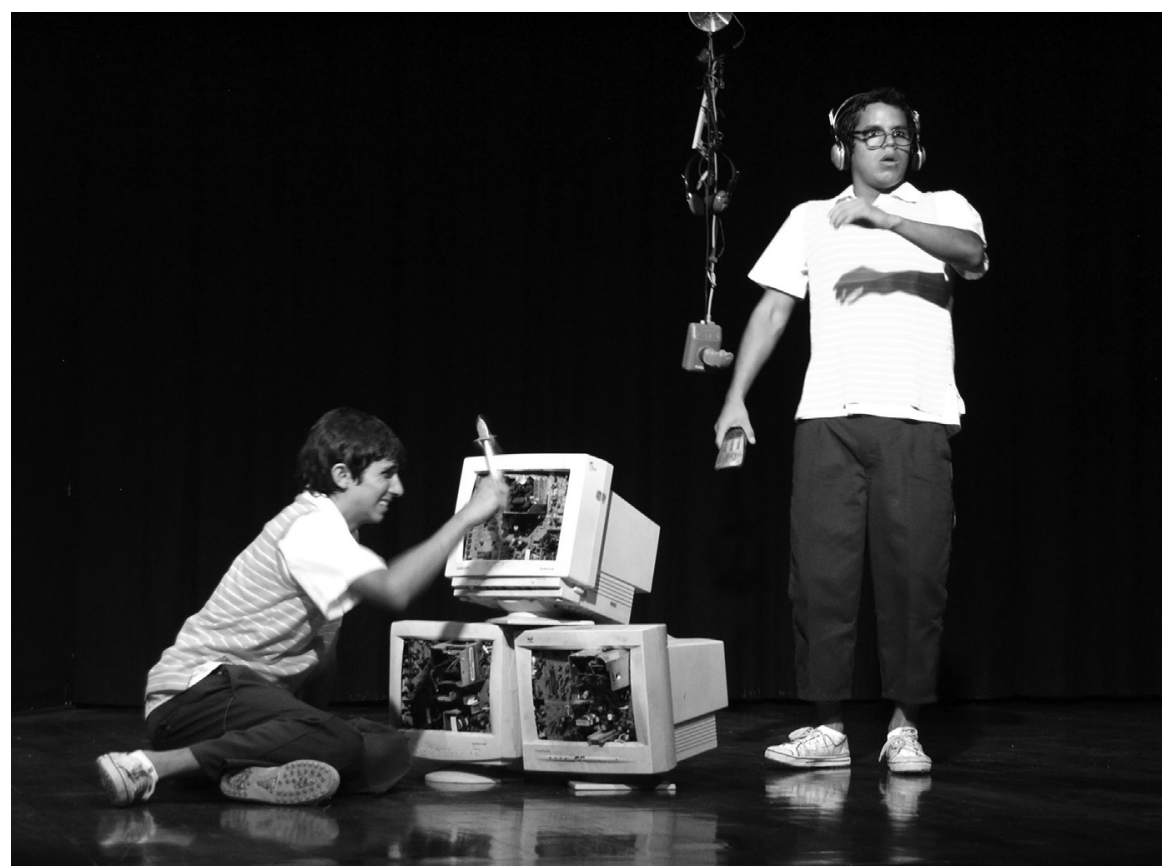

Interruptor. Photo: Jimmy A. Noriega 
play itself suggests that passivity leads to alienation and defragmentation of the human spirit.

On the last night of the festival, Teatro Tierra from Colombia presented their play La vorágine, based on José Eustacio Rivera's classic novel by the same name. Adapted and directed by Juan Carlos Moyano, the story involved ten actors that provided both the characters and scenery needed to weave between dozens of scenes with rapidity and ease. Following the story of two lovers who have escaped the city, the play is a journey through the country and jungles of Colombia, where life and death are in constant flux. The plot, a delirious and tragic story, poetically exposes the qualities and consequences of impulse, lust, gossip, and betrayal. The play was imaginatively staged with the use of eleven wooden boards, each approximately two meters long, which were constantly in movement to create each new setting. La vorágine was an excellent ending to a week that celebrated the creative and innovative spirit of Latin American theatre.

In addition to the work of these nine professional groups, each day of the festival featured the work of students, including five performances from Peruvian universities. Host UCSUR presented an original collective creation, Al limite, which wove scenes together on the subjects of environmental and health issues, including deforestation, endangered species, pollution, global warming, and the dangers of smoking. Students from the Teatro Universitario de San Marcos presented two short plays by Gregor Diaz, Con los pies en el agua and Cercados, which featured the stories of characters trying to survive destitution and marginalization. The group from the Universidad Nacional Pedro Ruiz Gallo, in Chiclayo, energetically performed El crédito, by Juan Rivera Saavedra, a hilarious piece commenting on the abuses and dangers associated with credit and debt. Students from Trujillo's Universidad Privada Antenor Orrego were also strong in their presentation of the classic Enrique Buenaventura piece La orgía, which offers a tragic look into the life of an older woman who relives her glorious past by hiring vagrants to play the roles of her former lovers. Pony, by Gustavo Ott, was presented by the Pontificia Universidad Católica del Perú. Telling the tale of a woman who is taken advantage of by her family, the play makes a commentary on the modern conditions of financial dependence, purchased degrees, and disregard for the female will.

The university groups from the United States and Mexico performed their pieces on Thursday and Friday evenings. Miami Dade College's Teatro Prometeo presented their collaborative creation Yo me llamo Virgilio Piñera, 
adapting Piñera's stories into a series of scenes and monologues that recreate the twisted and unstable world of the Cuban author's works. The Compañia Juvenil de Teatro del Tecnológico de Monterrey, presented Mexican playwright Alfonso Reyes' Ifigenia cruel. The adaptation of the Greek myth, staged by famed Mexican director José Caballero, tells the story of Orestes and his encounter with his sister Iphigenia who serves the goddess Artemis. Together the seven university groups showcased a growing talent and dedication that represents the future of Latin American theatre.

With workshops offered on movement, voice, and stage techniques, the professional artists provided training, mentorship, and encouragement to the students involved in the festival. In addition to this creative exchange, the festival's inauguration of the I Congreso Internacional de Teatro Contemporáneo promoted an intellectual exchange of work and ideas. With presentations from sixteen professionals from Peru, Argentina, Chile, and the United States, the conference featured papers on Peruvian and Latin American theatre, theatrical theory, Andean rituals, and intercultural performances. Creating a space for dialogue and exchange, the IV Festival UCSUR de Teatro Internacional was a successful week-long celebration of theatre, culture, diversity, and camaraderie. 